\title{
Income Multipliers In Input - Output Analysis: Case Of Vietnam
}

\author{
Duong Mạnh Hung, Nguyen Quang Thai, and Bui Trinh
}

\begin{abstract}
The question arises as to which income group will benefit from GDP growth? This paper assesses the success or failure of Vietnam's economic policy through an input output analysis, the research estimates the spread of final demand to type of income. It proposes some ideas for adjusting macroeconomic policies. In this article, value added is divided into income groups such as: Income of labor groups (labors in the state enterprises; labors in the non-state enterprises and in the FDI sector); operating surplus of state-owned enterprises; operating surplus of non-state sector and operating surplus of FDI sector.
\end{abstract}

Key Words - income, input-output, multipliers, Vietnam

\section{INTRODUCTION}

The average GDP growth of Vietnam in the period of $2008-2017$ was about $6.2 \%$, this is quite a high growth rate for countries in the world and in the region. However, the growth of Vietnam's economy is tending to decrease gradually, before joining the WTO, the average GDP growth of Vietnam during 1990-2000 was about 7.7\%, from 20002009. Average growth GDP decreased to 6.8\%, from 2009 2018 average GDP growth was $6.2 \%$. Thus, before joining the integration and the current period, the average GDP growth rate decreases by 1.5 percentage points.

The study uses the input-output system was developed by W. Leontief. In the 1930s, Wassily Leontief published a first paper that laid the groundwork for the later IO model [1]. W. Leontief applied the idea of François Quesnay to research, development and construction [2]. An input output table for the United States, this work focuses on describing the flow of transactions between industries of the economy. Next he introduced Leon Walras's idea of supply and demand to provide a framework for mathematically predefining the relationship not only of the relationship between industries but also the relationship of final demand to production and income [3].

Leon Walras argues that an economy has many types of products, so there are many equations of supply demand, when the supply and demand of the product meet, it will form the price of that product he said that the solution

Published on April 26, 2020.

Duong Mạnh Hung, the National Account Department - General Statistics Office of Vietnam.

(e-mail: dmhung74@yahoo.com)

Nguyen Quang Thai, Vietnam Development Research Institute, Vietnam.

(e-mail: thai.nguyenquang@gmail.com)

Bui Trinh, Vietnam Development Research Institute, Vietnam.

(corresponding e-mail: buitrinhcan@gmail.com) because the number of equations equals variables, W. Leontiefformalizes this idea by applying linear algebra and the theoretical framework from the matrix system applied by W. Leontief subtly to solve [4]. Miller and Blair also explain an IO table that describes "the flow of products from each industry considered a producer for each industry that is considered the buyer side" and that it is a "excellent description tool" [5]. It is also called "a powerful analytical technique" [6, 7]. In the manufacturing process, each industry uses products produced by other industries and produces outputs consumed by the final consumer (for private consumption, government consumption, investment and export) and other sectors such as inputs for intermediate consumption [8]. Other studies on IO models can be found in some studies $[9,10,11,12,13,14]$.

Today, the IO system of Leontief has been created and applied in most countries around the world; in 1968 the IO board was added to the National Accounts System and viewed as the center of this whole system[15].

Multiplier input - output can include input, output multipliers, and value-added multipliers. The total effects are understood to include the direct, indirect, inter-sectoral feedback and spillover effects of a change in demand that is ultimately defined by West [16].

In this research, the value added was divided as follows:

+ Compensation of employees was divided as below:

- Labor's income of state area

- Labor's income of non - state area

- Labor's income of FDI area

+ Operating surplus was divided as follow:

$$
\begin{array}{ll}
\text { - } & \text { State } \\
\text { - Non-State } & \text { No } \\
\text { - } & \text { FDI }
\end{array}
$$

+ Domestic final demand includes:

- Final consumption

- Gross capital formation of state sector

- Gross capital formation of non - state sector

- Gross capital formation of FDI sector

- Export of goods

- Export of services

The input - output table was used in research include 19 sectors in 2012

Table 1.19 sectors

\begin{tabular}{|r|l|}
\hline 1 & Agriculture, forestry and fishery \\
\hline 2 & Exploit \\
\hline 3 & Manufacturing and processing industry \\
\hline 4 & $\begin{array}{l}\text { Production and distribution of electricity, gas, hot water, steam } \\
\text { and air conditioning }\end{array}$ \\
\hline 5 & Electricity and water \\
\hline
\end{tabular}




\begin{tabular}{|r|l|}
\hline 6 & Construct \\
\hline 7 & Commerce \\
\hline 8 & Carriage \\
\hline 9 & Eat and stay \\
\hline 10 & post office \\
\hline 11 & Financial intermediation services \\
\hline 12 & Real estate business \\
\hline 13 & Science and technology \\
\hline 14 & Administrative and support services \\
\hline 15 & NN Management \\
\hline 16 & Education \\
\hline 17 & Medical \\
\hline 18 & Art \\
\hline 19 & Other services \\
\hline
\end{tabular}

\section{METHODOLOGY}

Leontief's basic relationship in competitive import type has the form:

$$
X=(I-A)^{-1} \cdot Y
$$

With: $\mathrm{X}$ is an output matrix that induced by factor of final demand, I is identify matrix, $\mathrm{A}$ is a direct coefficient matrix, and $\mathrm{Y}$ is matrix of final demand including final consumption, gross capital formation and net export. In this equation have two problems:

+ We cannot know how export induces to output

+ In matrix A includes domestic and import products. In many cases, final demand increase is only inducing to import.

So, in order to observe each factor of domestic final demand as final consumption, gross capital formation and export induce to output and production income needs to move the input - output table at competitive import type to non-competitive import type. That means matrix AX will be divide domestic input matrix $\left(A^{d} \mathrm{X}\right)$ and import input matrix $\left(A^{m} \mathrm{X}\right)$, we have:

$$
A X=A^{d} X+A^{m} X
$$

The final demand $\mathrm{Y}$ also is divided $Y^{d}$ and $Y^{m}$

Where: $Y^{d}$ includes $C^{d}, I^{d}$ and export

$Y^{d}=C^{d}+I^{d}+E$

And:

$$
Y^{m}=C^{m}+I^{m}
$$

Note that: $C^{d}$ and $C^{m}$ are final consumption products of domestic and import products corresponding; $I^{d}$ and $I^{m}$ is gross capital formation of domestic and import products corresponding.

From (1), (2), (3) and (4) we have:

$$
A^{d} X+A^{m} X+Y^{d}+Y^{m}-M=X
$$

Note: $A^{m} X+Y^{m}-M=0$

So:

$$
A^{d} X+Y^{d}=X
$$

Or:

$$
X=\left(I-A^{d}\right)^{-1} Y^{d}
$$

Equation (7) is seemed as basic relationship of input output table non - competitive import type:

Then: $X=\left(x_{i k}\right)_{(n \times k)}, \mathrm{n}$ is number of sectors in input output table and $\mathrm{k}$ is number of factors in final demand; matrix $\mathrm{X}$ includes output induced by final consumption $\left(X_{c}\right)$, output induced by gross capital formation $\left(X_{k}\right)$ and output induced by exports $\left(X_{E}\right) ; A^{d}=\left(a_{i j}^{d}\right)_{n \times n}=Z_{i j} / X_{j}$ with $Z_{i j}$ is intermediate input of product $\mathrm{s}$ fot sector $\mathrm{j}$

So, $A^{d}$ is a domestic input coefficient matrix, $Y^{d}$ is domestic final demand that includes domestic consumption $\left(Y_{C}^{d}\right)$, domestic gross capital formation $\left(Y_{I}^{d}\right.$ and export $\left(Y_{E}\right)$,

The problem is that not only does the final demand of imported products spread directly to imports, but even the final demand for locally-produced products stimulates imports through imports for intermediate costs. Ferran Sancho introduced the Armington principle to separate domestic production and imports for intermediate costs out of gross output, an idea that is interesting but can also disrupt the balance of technical norms for 1 unit of product $[17,18]$.Especially for developing countries, production is basically outsourcing. So, to consider the impact of the economy on imports this research apply import multiplier analysis in extending the standard multipliers incorporating an ad hoc intermediate imports factor [19].

$$
\text { Put } M^{p}=A^{m} \cdot X
$$

We have:

$$
M^{p}=A^{m} \cdot X=A^{m}\left(I-A^{d}\right)^{-1} Y^{d}
$$

$A^{m}\left(I-A^{d}\right)^{-1}$ Is import multipliers matrix for a unit increase of domestic final demand

Define that: $P=f_{\left(P_{C}, P_{I}, P_{E}\right)}$

That:

$$
\begin{aligned}
& P_{c}=\sum_{i}^{n} X_{c} \div \sum_{i}^{n} Y_{c}^{d} \\
& P_{I}=\sum_{i}^{n} X_{I} \div \sum_{i}^{n} Y_{I}^{d} \\
& P_{E}=\sum_{i}^{n} X_{E} \div \sum_{i}^{n} Y_{E}
\end{aligned}
$$

$(\div)$ is scalar divide

$P_{c}$ is output that induced impact by a unit increase of final consumption (C)

$P_{I}$ is output that induced impact by a unit increase of final investment / gross capital formation (I)

$P_{E}$ is output that induced impact by a unit increase ofexport (E)

$$
\begin{aligned}
& \text { Call: } v=\left(v_{i j}\right)_{k \times n} \mathrm{v} \\
& \text { Put: } v_{i j}=V_{i j} / X_{j}
\end{aligned}
$$


With: $\mathrm{k}$ is number component of value added, $V_{i j}$ is income of income group $\mathrm{i}^{\text {th }}$ of sector $\mathrm{j}^{\text {th }}$

Formalize by the matrix relationship we have:

$V=v\left(I-A^{d}\right)^{-1} Y^{d}$

$H=v\left(I-A^{d}\right)^{-1}$ Isan income multiplier matrix for a unit increase of domestic final demand.

\section{SOME FINDINGS}

Table 2 shows the income level of employees due to an increase in the final demand unit. On average, the increase in demand eventually produced the highest income for the non-state sector (0.191) and the lowest for foreign direct investment (0.06). Sectors that induce from final demand were service sectors. The effects of domestic final demand on the income of labors of the foreign direct investment sector are lowest in all sectors. There are 9 sectors that have a power of dispersion index higher than average income. These sectors are electricity and water (sector number 11); scientific and technological activities (sector number 13); Administrative and support services (sector number 14); Government services (sector number 15); Education (sector No. 16), Health and social activities (sector number17); other services (branch No. 19). The final demand of the sectors using the state budget (sectors No. 15, 16, 17) basically spread to the income of labors in the state sector.

\begin{tabular}{|c|c|c|c|c|}
\hline \multirow[b]{2}{*}{ TT } & \multicolumn{4}{|c|}{$\begin{array}{l}\text { Labor incomes induced by a unit increase of } \\
\text { domestic final demand by sectors }\end{array}$} \\
\hline & $\begin{array}{l}\text { Import } \\
\text { multipliers }\end{array}$ & State & Non-State & FDI \\
\hline 1 & 0.9605 & 0.2294 & 0.1476 & 0.0405 \\
\hline 2 & 0.746 & 0.1764 & 0.1001 & 0.0478 \\
\hline 3 & 0.7172 & 0.1042 & 0.1651 & 0.0425 \\
\hline 4 & 0.5426 & 0.1397 & 0.0783 & 0.0179 \\
\hline 5 & 10,901 & 0.3405 & 0.1147 & 0.0187 \\
\hline 6 & 0.9467 & 0.0937 & 0.2625 & 0.0554 \\
\hline 7 & 12,318 & 0.1415 & 0.3415 & 0.0525 \\
\hline 8 & 0.8598 & 0.1153 & 0.2102 & 0.0483 \\
\hline 9 & 0.9437 & 0.1325 & 0.1571 & 0.1207 \\
\hline 10 & 0.7608 & 0.1655 & 0.1109 & 0.0544 \\
\hline 11 & 11,266 & 0.2211 & 0.1857 & 0.083 \\
\hline 12 & 0.4776 & 0.0415 & 0.108 & 0.0581 \\
\hline 13 & 14,357 & 0.1193 & 0.2972 & 0.2077 \\
\hline 14 & 12,456 & 0.0886 & 0.3996 & 0.0533 \\
\hline 15 & 14,492 & 0.584 & 0.0337 & 0.0123 \\
\hline 16 & 14,300 & 0.3604 & 0.2052 & 0.0561 \\
\hline 17 & 11,004 & 0.2389 & 0.1999 & 0.0396 \\
\hline 18 & 0.6319 & 0.082 & 0.1317 & 0.061 \\
\hline 19 & 13,038 & 0.0958 & 0.3772 & 0.0938 \\
\hline Average & & 0.1827 & 0.1909 & 0.0613 \\
\hline
\end{tabular}

Source: Authors calculate from input-output table, 2012

Table 3 shows that the impact of domestic final demand on production surpluses is much lower than these effects on labor income ( 0.14 versus 0.43$)$. In some sectors are induced impacts by domestic final demand that is above the economy average, such as: Production and distribution of electricity, gas, hot water, steam and air conditioning (sector 4); Trade (sector 7); Finance, Banking, and Insurance operations (Sector No. 11); Real Estate (Sector No. 12); Education (sector No. 16); Arts and entertainment (branch 18); In particular, sector no. 4 and sector 12 have a very large spread of surpluses that are twice as high as the economy average, noting that sectors 4 and 12 induced to labors' $\mathrm{s}$ incomes are lower than these induced to operating surplus., almost lowest among the sectors studied; The question is area 4 is almost exclusively for the state sector and area 12 is strongly influenced by the "interest group"?

\begin{tabular}{|c|c|c|c|}
\hline \multirow[b]{2}{*}{$\mathrm{TT}$} & \multicolumn{3}{|c|}{$\begin{array}{c}\text { Operating surplus induced impacts by a unit increase of } \\
\text { domestic final demand }\end{array}$} \\
\hline & State & Non-state & FDI \\
\hline 1 & 0.0738 & 0.0417 & 0.0196 \\
\hline 2 & 0.0167 & 0.0128 & 0.0117 \\
\hline 3 & 0.03 & 0.0275 & 0.0396 \\
\hline 4 & 0.2062 & 0.0995 & 0.0219 \\
\hline 5 & 0.0435 & 0.019 & 0.0093 \\
\hline 6 & 0.0186 & 0.0324 & 0.0181 \\
\hline 7 & 0.0494 & 0.112 & 0.0226 \\
\hline 8 & 0.0311 & 0.0493 & 0.021 \\
\hline 9 & 0.0357 & 0.0375 & 0.0342 \\
\hline 10 & 0.0231 & 0.0185 & 0.014 \\
\hline 11 & 0.0886 & 0.0746 & 0.0351 \\
\hline 12 & 0.0517 & 0.1503 & 0.0958 \\
\hline 13 & 0.0157 & 0.0272 & 0.0195 \\
\hline 14 & 0.0211 & 0.0777 & 0.0163 \\
\hline 15 & 0.1127 & 0.0084 & 0.0056 \\
\hline 16 & 0.1219 & 0.07 & 0.0218 \\
\hline 17 & 0.0223 & 0.0193 & 0.0137 \\
\hline 18 & 0.0674 & 0.109 & 0.0582 \\
\hline 19 & 0.0195 & 0.0419 & 0.0181 \\
\hline verage & 0.0552 & 0.0541 & 0.0261 \\
\hline
\end{tabular}

Source: Authors calculate from input - output table, 2012

Table 4 shows that most of the domestic final demand factors except investment from the FDI and the export of goods are almost induced exclusively for labors' incomes and operating surplus of state and non-state areas. While the investment of FDI sector and export of goods mostly spread to the FDI sector both in terms of labor income and operating surplus, it seems that there are two economies in the economy. The domestic and FDI sectors seem to be independent in the Vietnamese economy.

\begin{tabular}{|c|r|r|r|r|}
\hline & Table 4: Output, income and operating surplus multipliers (times) & \\
\hline Induced by: & $\begin{array}{c}\text { Final } \\
\text { consumption }\end{array}$ & $\begin{array}{c}\text { Gross } \\
\text { capital } \\
\text { formation }\end{array}$ & $\begin{array}{c}\text { Export } \\
\text { of } \\
\text { goods }\end{array}$ & $\begin{array}{c}\text { Export } \\
\text { of } \\
\text { services }\end{array}$ \\
\hline Gross output & 1,662 & 1,864 & 1,882 & 1,701 \\
\hline Labor's income & 0,653 & 0,704 & 0,652 & 0,678 \\
\hline State & 0,281 & 0,220 & 0,150 & 0,240 \\
\hline Non-State & 0,285 & 0,391 & 0,318 & 0,310 \\
\hline FDI & 0,087 & 0,093 & 0,185 & 0,127 \\
\hline Operating surplus & 0,216 & 0,179 & 0,203 & 0,207 \\
\hline State & 0,086 & 0,060 & 0,073 & 0,074 \\
\hline Non-State & 0,079 & 0,068 & 0,068 & 0,080 \\
\hline
\end{tabular}




\section{CONCLUSION}

The results of this study show that the domestic final demand that spreads to the income of workers is higher than the spillover to operating surplus; especially both power of dispersion of labor's income and operating surplus of the manufacturing group are lower than average of economy.

Producing and distributing electricity, gas, hot water, steam, and air conditioning has the power of dispersion index on labor 'income is very low, but the power of the dispersion index on operating surplus is very high. Noting that electricity is almost a monopoly of the state, the electricity price almost increases every year, all the continuous increase in electricity price makes the industry's surplus outstanding?

Investment of FDI sector and export of goods are almost exclusively spread to FDI sector without any significant spillover effects on other areas as desired by the government and the public as they step in international integration. The FDI sector and domestic economic activities do not seem to have much cohesion and thus the government's efforts to attract FDI through tax incentives and favorable conditions various has not obtained results in this sector.

The FDI sector has the "dominant position in export" but has little interaction with the domestic market; the policy makers should be finding sectors that have power and sensitivity high indexesof domestic economy in order to invest for increasing inter-industrial interaction. It is also important to increase of inter-sectoral feedback effects in value chains of products

This study also suggests that Vietnam should reevaluate the cost benefits of FDI attraction policies and make the necessary policy adjustments to ensure that the offered work is commensurate with the contribution of that party, it is necessary to enhance the playing field and create fairer and fairer treatment of other "players" of the economy: All economic sectors should be treated fairly and transparent.

\section{REFERENCES}

[1] Leontief, W."Quantitative Input and Output Relations in the Economic Systems of the United States". The Review of Economics and Statistics, 18, 105-125.https://doi.org/10.2307/1927837, 1936

[2] Eltis, W. "Francois Quesnay: A Reinterpretation the Tableau Economique". Oxford Economic Papers, 27(2), new series, 167-200. Retrieved February 8, 2020, from www.jstor.org/stable/2662336, 1975

[3] Walras, L."Élémentsd'Économie Politique Pure". Paris, $4^{\text {me }}$ ÉditionDéfinitive ET Augmentée par l'Auteur 1926, (R. Pichon et R. Durand-Auzias Eds.), 1874

[4] Wassily, W "Structure of the American economy", 1919-1929, Harvard University Press: Cambridge Mass, 1941),

[5] Miller, R, Blair, P, "Input-Output Analysis-Foundations and Extensions", New Jersey: Prentice-Hall, Englewood Cliffs, 1985

[6] Jensen, R,C, Mandeville, T,D, Karunaratne, N,D, "Regional Economic Planning: Generation of Regional Input-Output Analysis", London: Croom Helm, 1979

[7] M, Muchdie, H, Kurniawan 'Import Components and Import Multipliers in Australian Economy: World Input-Output Analysis', International Journal of Economics and Financial Issues, 2018, 8(2), 304-314;2018

[8] Oosterhaven, J, Stelder, D, Regional and Interregional IO Analysis", The Netherlands: Faculty of Economics and Business University of Groningen, Avalable, 2007
[9] Richardson, H, W, "Input-output and economic base multipliers: Looking backward and forward', Journal of Regional Science, 25(4), $607-661 ; 1985$

[10] Hewings Geoffrey, "Regional input - output analysis", Beverly Hills: Sage Publications; 1985

[11] Thao, N, P, 'An Analysis for the Northern Key Economic Region: Vietnam Based on the Input-Output Table Noncompetitive Style', Journal of Finance and Investment Analysis, 3, 37-47; 2014

[12] Tran, T, et al, 'Finding Economic Structure and Capital Structure for a "Greener" Economy', Journal of Economic Research, No, 13, 31533167; 2016

[13] Bui, T, and Pham, L, H, "Some findings of Vietnam's economic situation in the relationship with China", American Journal of Economics, 4(5): 213-17; 2014

[14] Bui Trinh, Bui Quoc, "Some Problems on the Sectoral Structure, GDP Growth and Sustainability of Vietnam", Journal of Reviews on Global Economics, 2017, 6, 143-153;2017

[15] United Nations (1968) "A System of National Accounts", New York: United Nations, Series F, no. 2, rev. 3.1969

[16] West, M. A. "The social psychology of innovation in groups". In M. A. West \& J. L. Farr (Eds.), Innovation and creativity at work: Psychological and organizational strategies (p. 309-333). John Wiley \& Sons.; 1990

[17] Sancho, F "An Armington-Leontief model". Economic Structures 8, 25. 2019

[18] Armington P "A theory of production distinguished by place of production". IMF Staff Pap 16(1):158-178; 1969

[19] Trinh, B., Hoa, P. L., \&Giang, B.C. (2008). Import multiplier in inputoutput analysis. Depocen Working Paper Series No. 232008. 


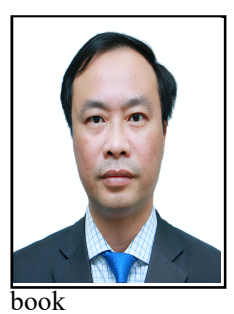

First author: Duong Manh Hung

General Statistic Office 54 Nguyen Chi Thanh st, Dongda, Hanoi, Vietnam, Got Master at Hanoi National Economic University.

Work experience: worked at National Account Department under GSO of Vietnam since 1997. Currently, being Director of National Account Department.

Number of published papers: 10 articles and one

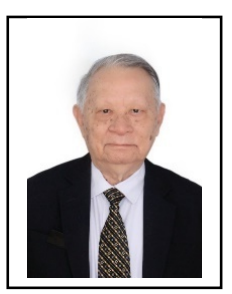

Second author: Prof. Dr. Sc Nguyen Quang Thai.

$\mathrm{He}$ has been teaching in Hanoi National University from 1963 until 1970 from 1970-2007worked in some Research Institutes. Now he is member of Science\& Education Council of National Economics University, President of Vietnam Development Research Institute

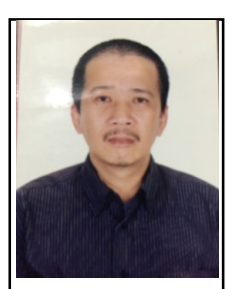

\section{Third Author: Bui Trinh (PhD)}

He was born at Hanoi in September.1960, he graduated at mathematic department of Hanoi National university, after that he got $\mathrm{PhD}$ at Kyoto university

He worked at National Account Department under General Statistics Office of Vietnam from 1982 until 2016. From 2016 to now he worked at Vietnam development research institute, he also is research fellow of association of Regional Econometrics and Environmental Studies (AREES) - Japan. He had 61 articles, three chapters of books, two books (based on research Gate). 